\title{
LIVROS DIDÁTICOS E ENSINO DE HISTÓRIA: A IDADE MÉDIA NOS MANUAIS ESCOLARES DO ENSINO FUNDAMENTAL
}

\author{
TEXTBOOKS AND TEACHING OF HISTORY: A HAND IN THE MIDDLE AGES \\ OF ELEMENTARY SCHOOL STUDENTS
}

Edlene Silva $^{1}$

\begin{abstract}
RESUMO: Este artigo analisa as representações sobre a Idade Média presentes em alguns dos manuais escolares produzidos no Brasil após o Programa Nacional do Livro Didático (PNLD) implementado em 1996. Busca ainda entrever as distâncias e aproximações entre o saber acadêmico e o saber escolar, além de possíveis rupturas e permanências no olhar pejorativo sobre a Idade Média, que se mantém presente no ensino de História nas escolas brasileiras.
\end{abstract}

Palavras chaves: Livro didático. Ensino de História. PNLD. Idade Média.

\begin{abstract}
This paper deals with the representations of the Middle Ages in the textbooks produced in Brazil after the National Textbook Program (PNLD), in 1996. It points out also distances and approaches between academic knowledge and school knowledge, and possible ruptures and continuities in the pejorative idea about the Middle Ages in history teaching in Brazilian schools.
\end{abstract}

Keywords: Textbooks. Teaching History. PNLD. The Middle Ages.

\footnotetext{
${ }^{1}$ Historiadora e professora adjunta da área de Teoria e Metodologia do Ensino de História do Departamento de História da Universidade de Brasília. Representante do Laboratório de Ensino de História da Universidade de Brasília (LABEH).
} 


\section{Introdução}

A partir de 1996, o Estado brasileiro implementou o PNLD (Programa Nacional do Livro Didático) e passou a exercer uma fiscalização efetiva sobre a qualidade dos livros didáticos distribuídos na rede pública de ensino em todo o país. Desde então, a aquisição dos manuais escolares com verbas federais para a distribuição gratuita em território nacional está condicionada a inscrição e avaliação prévias, segundo regras estabelecidas em edital próprio. Só entram no Guia do Livro Didático as obras que passarem pelo crivo da comissão criada pelo MEC para selecionar os materiais que obedecerem aos critérios de qualidade. Não são admitidos livros com erros de informação, de conceitos ou com desatualizações graves. Também estão excluídos manuais com ideias que reproduzam preconceitos de gênero, condição social, etnia ou quaisquer formas de proselitismo, além de incoerências metodológicas graves entre a proposta explicitada e aquilo que foi efetivamente apresentado ao longo da obra (MIRANDA; LUCCA, 2004). Nesse sentido, muitos estudiosos, dentre eles, Bittencourt (2003); Miranda e Lucca (2004) entendem que a intervenção estatal forçou uma significativa mudança de qualidade dos livros didáticos no país.

A ideia deste artigo é verificar se, de fato, essa qualificação vem ocorrendo ou se mesmo com os mecanismos de controle, as representações reducionistas e anacrônicas subsistem. A experiência como professora de História nos ensino fundamental, médio e superior motivou a elaboração dessa pesquisa.

\section{Livro Didático o Ensino de História}

A disciplina História está entre aquelas consideradas pelos estudantes como umas das mais enfadonhas. Não é incomum que os alunos classifiquem-na como "decoreba", "descritiva" e "monótona". Comumente as aulas centram-se na cronologia, restringindo o estudo histórico aos fatos e datas, grandes personagens e acontecimentos. Em sua maioria, esses 
dados factuais são fundamentados apenas pelo livro didático considerado como "principal veiculador de conhecimentos sistematizados, o produto cultural de maior divulgação entre os brasileiros que têm acesso a educação escolar" (FONSECA, 2003, p.49). O contato direto com diferentes referências documentais e a problematização da realidade estudada por meio de fontes de época, bem como a utilização de outros suportes pedagógicos, são espaços lacunares no ensino de História nas escolas.

O uso exclusivo do manual escolar como recurso didático em sala de aula influi diretamente na vida dos alunos, significando, muitas vezes, a única referência histórica a que eles terão acesso. Tal prática educacional implica na reprodução de concepções e métodos de ensino pré-concebidos, sem levar em conta a necessidade de trabalhar com fontes diversificadas que podem e devem contribuir para a construção do conhecimento histórico.

(...) a imensa maioria, praticamente quase o total do alunado, não lerá no futuro outros livros de História, nem terá informações históricas de fontes mais adequadas, é o texto escolar, o compêndio, o instrumento privilegiado que marcará a visão e o entendimento da história ensinada ao aluno. Este orientará seus conhecimentos vividos e historicizados, como interpretações e versões dos fatos tidos memoráveis, provavelmente para o resto da vida (MELO, 2008, p.29)

O livro didático por muito tempo foi tido como detentor de autoridade "incontestável" e referência de qualidade de ensino para professores, estudantes e pais. No século $X X$, passou a ocupar papel de destaque, devido, dentre outros motivos, a sua capacidade sistematizadora dos conteúdos ministrados em sala de aula. Ele encerra em si quase todas as etapas da prática pedagógica, não se atendo apenas ao que deve ser ensinado (conteúdo, abordagens, objetivos), mas como se ensinar (metodologia, recursos didáticos). Nas últimas décadas, o livro didático redefiniu o contexto escolar, determinando parâmetros do que se considera um bom professor, uma boa aula e uma boa escola. (FISCARELLI, 2006)

Portanto, análises e pesquisas sobre o livro didático são imprescindíveis, pois esses materiais possuem um caráter normativo e 
constroem representações sociais, difundindo valores e ideologias que refletem diretamente na formação identitária dos alunos.

Hoje, a escolha e uso do livro didático geram polêmicas e suscitam calorosos debates quanto a seus limites e possibilidades. As opiniões sobre o impacto e relevância desses materiais na educação escolar são diversas. Algumas vozes apontam para as particularidades da educação brasileira e para o papel dos livros didáticos, não apenas como suporte pedagógico, mas como principal fonte de informações para o professor. Não raramente, entretanto, esses manuais são considerados vilões do Ensino de História, pois cristalizam conteúdos, empobrecem as análises e acabam por respaldar a separação entre ensino e pesquisa. Alguns críticos chegam a defender que melhor seria não os adotar e substituí-los por outras fontes. Há, contudo, aqueles que buscam alternativas para a utilização dos livros didáticos, entendendo suas dimensões e complexidades (BITTENCOURT, 2004, p.300).

O processo de produção e distribuição do livro didático atende a múltiplas variáveis que englobam desde as políticas educacionais e investimentos financeiros, até aprovação de uma legislação que oriente as plataformas curriculares. Depois de uma fase pós-ditatura em que o manual escolar deixou de ser um suporte doutrinador do regime, avaliado pelo governo com minúcia, em meados da década de 90 volta a ser, cada vez mais, um reflexo da política educacional do Estado. Não mais uma política ditatorial, como ocorreu na época do regime militar, mas uma política desenvolvida em um contexto democrático.

De manuais auxiliares do processo de ensino-aprendizagem, os manuais didáticos passaram a ser cada vez mais reconhecidos e indicados, nas políticas educacionais, como documentos de importância estratégica para viabilizar as mudanças e melhorias que se fazem necessárias na educação básica dos países em desenvolvimento, inclusive demonstrando maior efetividade do que a produção de propostas curriculares inovadoras (MONTEIRO, 2009, p.179)

Exemplo desse controle estatal é a adoção do Programa Nacional do Livro Didático (PNLD) de 1996 e dos Parâmetros Curriculares Nacionais- 
PCN's de 1997/1998. Enquanto discurso autorizado do governo, os PCN's legitimam e reconhecem o uso dos manuais e apostilas didáticas no sistema educacional brasileiro pois, atendem as expectativas e concretizam modelos, concordâncias e aceitações por parte de um grande número de agentes sociais e institucionais.

Para o Estado e algumas escolas particulares, representam um instrumento de controle do sistema escolar, a garantia de uma certa qualidade de ensino e difusão de valores. Para o professor, asseguram um modelo de prática, segurança no processo de desenvolvimento do trabalho e eficiência na transmissão de conteúdos exigidos por programas e currículos. Para as famílias, expressam um sinal de qualidade da educação. E para a indústria editorial garantem um mercado certo e seguro ${ }^{2}$. (PCN'S, 1998, p.79)

No entanto, apesar do elogio ao uso do manual escolar, os Parâmetros indicam a necessidade de sua abordagem crítica, propondo a diversificação das fontes na educação (1998, p.81). Defendem a ideia de que o livro didático não pode ser encarado como portador de histórias prontas e acabadas, nem confundidas com a realidade vivida pelos homens do passado. Como qualquer texto historiográfico, o livro didático de história apresenta visão específica do passado, elaborada a partir de valores, intencionalidades e contextos sociais, culturais e institucionais dos autores. Assim, são imprescindíveis os esforços de compreensão dos critérios de seleção dos eventos narrados, da eleição de personagens e das próprias estruturas narrativas de tais livros. Portanto, o próprio livro didático deveria ser objeto de indagação, envolvendo os vários elementos que interferem na sua produção, circulação e consumo. (1998, p.33)

Por este caminho, o uso do livro didático em sala de aula, ao invés de significar a apropriação acrítica de conteúdos e valores, pode oferecer a oportunidade de produção de conhecimento, reflexão e compreensão das relações estabelecidas entre os acontecimentos, os sujeitos históricos e as coletividades no tempo.

2 As vendas de livros didáticos correspondem a quase metade do mercado editorial brasileiro. O PNLD é o maior responsável por esse fenômeno. Em 2007, por exemplo, o governo gastou 624 milhões de reais milhões de reais na compra de manuais escolares. 
Para entender o livro didático é preciso analisá-lo em seus múltiplos aspectos e contradições. O professor necessita ter familiaridade com as novas teorias e metodologias históricas e com os pressupostos que as orientam, pois "somente com muita habilidade e formação especifica o professor conduz uma turma a discussões contraditórias a partir de um texto didático" (MELO, 2008, p.17-18).

Nas aulas de História Medieval que ministrei entre 2003 e 2007 em Institutos de Ensino Superior do DF pode-se perceber a força representacional do livro didático no imaginário do aluno. Sempre, no primeiro contato com a turma, perguntava qual a ideia que tinham de Idade Média, as respostas eram similares e, em sua maioria, depreciativas: barbárie, guerras, fome, peste, analfabetismo, miséria, obscurantismo, exploração dos camponeses, Inquisição e Cruzadas. Quando perguntava onde tinham aprendido isso, respondiam prontamente: "na escola! Tá nos livros didáticos professora!"

A Idade Média é uma das áreas da História abordada de forma mais pejorativa. Como pontua Régine Pernoud: "não há dia em que não encontre uma reflexão do tipo: 'não estamos mais na Idade Média', 'é um retorno à Idade Média' ou 'é uma mentalidade medieval'" (1994, p.08). A autora reconhece que o imaginário depreciativo sobre o medievo começa na escola, desde muito cedo. Certa vez, em uma aula de História em que acompanhava seu sobrinho de 7 ou 8 anos, ela presenciou o seguinte diálogo:

Professora: Como se chamavam os camponeses na Idade Média?

Coro da turma: eles se chamavam servos.

Professora: Que é que eles faziam, o que é que eles tinham?

Turma: eles tinham doenças

Professora: Que doenças Jerônimo?

Jerônimo (sério): Peste

Professora: Que mais, Emanuel?

Emanuel (entusiasmado): Cólera!

Professora: Vocês sabem muito bem História. Passemos à Geografia... (1994, p.08). 
Pernoud escreveu seu texto em 1994 e suas reflexões ainda permanecem atuais. Apesar da reabilitação gradual que a Idade Média vem adquirindo nos últimos anos, no âmbito das universidades, é comum que as problematizações acadêmicas não cheguem aos manuais escolares. Muitas vezes, o medievo ainda é visto como um retrocesso, se comparado a Antiguidade Clássica, e um atraso em relação à Idade Moderna e à contemporaneidade.

Medievalistas, dentre eles, Heers (1994); Pernoud (1994, 1981); Le Goff (1995), Franco Júnior (1988), Macedo, (2008) já discutiram exaustivamente essa questão propondo novos olhares sobre a Idade Média. Porém, nos livros didáticos analisados, a concepção negativa do medievo prevalece, apesar das mudanças de enfoque em determinados assuntos, e ainda que os autores não utilizem o termo "Idade das Trevas" e questionem sua inadequação.

Deve-se lembrar de que a barreira separando a Idade Média da Idade Moderna é arbitrária e só se justifica por questões metodológicas, pois inúmeros conceitos, representações e instituições considerados modernos são originários da tradição medieval. Um exemplo notório é o da concepção de universidade surgida e implementada na Idade Média no século XIII.

Essas ponderações não tencionam apenas valorizar as permanências entre os dois períodos, mas também destacar continuidades e atualizações, pois muitas práticas medievais foram adaptadas, ressignificadas e reelaboradas a partir das necessidades modernas. Macedo refletindo sobe o ensino da Idade Média no Brasil questiona:

Qual o papel da escola, e da História que aí é ensinada, na difusão de conhecimentos relativos ao período? Antes, caberia perguntar qual Idade Média vem a ser divulgada nos bancos escolares e qual a pertinência de seu ensino num país como o Brasil, que não participou diretamente de uma experiência histórica propriamente medieval. (2008, p.111)

Independente do nosso país não ter participado diretamente de uma experiência propriamente medieva, a compreensão da História nacional parte da sua articulação com a tradição medieval cristã. Ignorar a permanência de elementos medievais na formação da sociedade brasileira é 
incorrer em grave erro, já que o medievo não pode ser compreendido somente como um recorte temporal arbitrário e convencional. Ele é, antes de tudo, um conjunto de práticas e representações sociais e culturais surgidas em uma dada época que podem perdurar em outros períodos históricos. No caso do Brasil, por exemplo, a festa popular mais característica do país é o carnaval, celebração originária na Europa medieval (século XI) que antecede os festejos da Semana Santa. É uma alusão ao "adeus à carne" ou carne vale antes do período de purificação e preparação para Páscoa denominado de quaresma.

Na obra O Teatro dos Vícios do historiador Emanuel Araújo (1993) registra que o Brasil foi povoado e construído "sob o signo do provisório", mantendo vários hábitos e estruturas da Idade Média, apesar de ser colonizado no contexto da modernidade. Filomena Coelho nos lembra que,

embora o Brasil só surja na História depois do fim "oficial" da Idade Média, também será construído com a mesma argamassa. Para nos conhecermos como brasileiros, não basta a identificação de nossas raízes africanas e indígenas; precisamos fazer o caminho inverso ao de Pedro Álvares Cabral e descobrir o que temos de Portugal, o que temos de medieval (2009, p.01)

Por outro lado, alguns autores como Pierre Bonnassie se contrapõe a essa visão e incidem suas análises nas rupturas, alegando que existe um profundo distanciamento entre o mundo contemporâneo e a Idade Média:

A Idade Média está, seguramente, bastante longe do nosso quotidiano e das nossas preocupações habituais... muito abrevidamente, é um outro mundo, um mundo claramente diferente do nosso, muito exterior às nossas actuais formas de falar, pensar, viver ou mesmo sentir. É uma realidade bem diversa (e é importante insistir na diferença) é, uma realidade para cujo estudo e compreensão se torna útil despertar o "apetite" (1985, p.7)

Todavia, é necessário pensar que a compreensão dos nossos dilemas atuais não pode ser explicada unicamente a partir de acontecimentos restritos ao presente. Requer questionar o passado e analisar as relações entre vivências sociais nas diferentes temporalidades. $O$ imaginário medieval, ao mesmo tempo tão perto e tão longe de nós, é uma referência 
imprescindível para compreensão da Civilização Ocidental, um momento de gestação da sociedade moderna e contribui decisivamente para o seu surgimento:

Esta longa Idade Média é para mim o contrário daquele ato visto pelos humanistas da Renascença e, salvo raras exceções, pelos homens do Iluminismo. Trata-se do momento da criação da sociedade moderna. De uma civilização moribunda ou morta nas suas formas camponesas tradicionais, mas viva por aquilo que ela criou de essencial nas estruturas sociais e mentais. A Idade Média criou a cidade, a nação, o Estado, a universidade, o moinho e a máquina, a hora e o relógio, o livro, o garfo, a lingerie, a pessoa, a consciência e finalmente a revolução. (LE GOFF, 1985, prefácio)

\section{O Medievo nos Textos Didáticos}

Dos manuais escolares que foram selecionados no PNLD após 1996, o artigo analisará dois deles: "História e Vida", de Claudino Piletti e Nelson Pilleti, edições de 2001 e 2005 e "Nova História Critica" de Mário Schmitt, edições de 1999 e 2003. A escolha dessas fontes está relacionada ainda com a proeminência do seu uso nas escolas públicas do Distrito Federal ${ }^{3}$.

O livro dos Pilleti introduz o conteúdo sobre a Idade Média caracterizando-a da seguinte maneira:

(...) sociedade - muito diferente daquela do Império Romano era rigidamente hierarquizada e marcada pela fé em Deus e pelo controle da Igreja católica, a instituição mais poderosa de toda a Idade Média. O poder político era descentralizado, isto é, estava nas mãos de inúmeros senhores de terra. Por todas essas características, muitos estudiosos acabaram chamando esse momento da história européia de Idade das Trevas. Eles acreditavam que o mundo medieval tinha soterrado o conhecimento produzido por gregos e romanos. (...) O certo é que durante esses mil anos a sociedade européia construiu

\footnotetext{
3 Esta constatação faz parte dos resultados de pesquisas realizadas nas escolas da rede pública de ensino do GDF apresentados no I Fórum de Socialização do Estágio Supervisionado do Curso de Licenciatura em História da Universidade de Brasília, realizado em 31 de janeiro, 1 e 2 de fevereiro de 2011 que coordenei em parceria com a Prof. Dra. Susane Rodrigues (HIS-UnB).
} 
seus valores culturais, que iriam se espalhar por todo o mundo a partir do século XV. (...) Nos próximos capítulos, iremos conhecer a sociedade medieval. Você poderá chegar as suas próprias conclusões sobre o significado da Idade Média (2001, p.149).

Mas qual a Idade Média apresentada para que os alunos cheguem a suas próprias conclusões? Vejamos algumas afirmações reducionistas presentes na obra: "um mundo rural e auto-suficiente" (2001, p.150); "rigidamente organizada, a sociedade feudal quase não permitia mobilidade social. Aquele que nascia servo estava destinado a produzir, por toda a vida, o sustento de senhores feudais e das autoridades religiosas" (2001, p.150); "a sociedade medieval era dividida em três ordens: a do clero, a dos guerreiros e a dos camponeses" (2001, p.153). "O rei apesar de seu poder simbólico, tinha poderes apenas em seu próprio feudo. Sua vantagem era não dever obrigações de vassalos dentro de seu reino a outro senhor" (2001, p.152); "Os servos não tinham a propriedade da terra e estavam presos a ela" (2001, p.153). O "inicio é 476 (queda do Império Romano) e seu final é 1453 (conquista de Constantinopla pelos turcos otomanos) ou a chegada dos europeus na América" (2001, p.149). Esta última opinião é partilhada por Schmidt: "o nascimento do período localiza-se em 476 e seu final em 1453" (1999, p.21).

Os autores não problematizam a divisão das três ordens: servos, nobres e clero para explicar a realidade social da Idade Média. É como se no medievo só existissem essas três categorias sociais e elas fossem bem definidas, com um papel específico e único a desempenhar, separadas umas das outras, sem entrelaçamentos e nuances entre si. Silencia-se toda e qualquer mobilidade social ou concomitância de papéis, ignorando que: bispos podiam ser senhores (muitos de origens humildes); nobres podiam também ser comerciantes e professores; um burguês poderia se tornar nobre ao comprar terras e títulos de nobreza (ou seja, a nobreza é hereditária, mas também adquirida); camponeses ou gente oriunda de estratos inferiores, por meio dos estudos universitários podiam se tornar administradores, advogados e altos funcionários reais. 
Nem todos os servos medievais são desprovidos da propriedade da terra ou presos a ela. Existiam camponeses livres e os que possuíam terras próprias, os alódios, ou seja, eram proprietários que não dependiam de um senhor e/ou gozavam de uma função hierárquica privilegiada que o senhor era obrigado a respeitar. A escravidão também não deixou de existir, sobretudo nas regiões italianas, mesmo que a mão-de-obra servil predominasse.

O rei não era um personagem simbólico ou um monarca fraco. Diante da fragmentação do poder na sociedade medieval, a centralização monárquica não existia, não havendo lugar para uma monarquia absoluta. Porém, o soberano era visto como um chefe de família, defendendo interesses coletivos e individuais. A natureza da monarquia medieval é de um rei justiceiro. Seu domínio sobre outros senhores é indireto, devendo zelar pelos costumes (respeitando tradições e privilégios), mas também manter a ordem. O monarca medieval era árbitro designado a apaziguar os conflitos entre os vassalos. Tal poder pode parecer platônico frente à autoridade dos grandes senhores feudais e do alto clero, mas o prestígio que Ihe confere a sacralização do seu posto revela-se eficaz, contrariando a imagem do soberano como uma "figura decorativa", a despeito de sua autoridade se sustentar mais em sua força moral do que em efetivos militares e econômicos. Na França e na Inglaterra medieval, por exemplo, aos monarcas era atribuído o dom de fazer florescer a terra infértil e o epíteto de taumaturgos, ou seja, a capacidade de curar doenças de pele e outros males. (Cf. BLOCH, 1993). Tais dons especiais, exclusivos da sagração monárquica, são elucidativos do papel do rei no medievo.

Havia na sociedade medieval rural uma tendência à auto-suficiência, mas este não era um mundo fechado ou completamente independente, nem incomunicável com o universo citadino e comercial. As próprias dificuldades da produção agrícola ou a existência de excedentes de produção forçavam o comércio entre feudos ou a comercialização nas feiras.

Deve-se mencionar que a visão do medievo como um mundo rural fechado no qual o comércio é inexistente relaciona-se com a tese do historiador Henri Pirenne, hoje pouco aceita na academia. Pirenne argumentava que após conquista muçulmana os contatos entre o Oriente e 
Ocidente foram interrompidos, o comércio desapareceu e as cidades decaíram, forçando a sociedade ocidental a se ruralizar completamente.

Diversos historiadores se opuseram a essa abordagem como Rennée Doechaerd, para o qual as conquistas muçulmanas não afetaram as relações Ocidente e Oriente e o mediterrâneo jamais foi um mar deserto ou completamente fechado aos ocidentais,

pois a marinha bizantina continuou ainda por um bom tempo a dominar o mediterrâneo. (...) Assim, o tráfico mediterrânico tornou-se intenso no centro, região de relativa segurança, o que beneficiou a Península Itálica, transformada numa das principais vias de importação de produtos orientais, posição mantida nos séculos seguintes. (apud FRANCO-JÚNIOR, 1988, p.45)

Franco-Júnior lembra que os produtos também penetravam no Ocidente por meio da Espanha muçulmana, onde mercadores francos e judeus iam buscá-los (1988, p.46). No entanto, as ideias de Pirenne ainda são reproduzidas nos livros didáticos. Os Pilleti defendem o "ressurgimento do comércio e das cidades" como se estas tivessem desaparecido e uma pretensa "abertura" do mar Mediterrâneo. Já Schmidt alega equivocadamente que "o uso das moedas foi abandonado (1999, p.27)".

um dos fatores responsáveis pelo ressurgimento do comércio e das cidades na Europa foram as cruzadas, pois elas contribuíram para o restabelecimento das relações entre Oriente e Ocidente e para a abertura do mar Mediterrâneo aos mercadores da Europa ocidental. (PILLETI; PILLETI, 2001, p.184)

(...) o comércio, fundamentado antes na simples troca de produtos, passou a se basear na troca de produtos por moeda. (PILLETI; PILLETI, 2001, p.185)

Tais visões servem para referendar uma oposição entre campo e cidade, como dois mundos em confronto, e explicar o surgimento do capitalismo como fator externo ao universo feudal, responsável pela sua derrocada. Essa concepção não leva em conta que as práticas mercantilistas eram parte da mentalidade clerical e nobiliárquica na Idade Média. O crescimento das cidades e do comércio não é um fenômeno restrito aos 
burgueses, mas impulsionado pela aristocracia, clero e rei que buscavam diversificar suas atividades econômicas. Elementos que caracterizavam as práticas capitalistas surgiram no seio do sistema feudal e não exógenos a ele.

Como explicitado antes, a sociedade medieval permitia considerável mobilidade social conforme os parâmetros da época. Servos fugiam dos laços compulsórios da servidão e nas cidades podiam se aventurar no comércio, por exemplo, e ascender socialmente. Havia a possibilidade de mobilidade horizontal no grupo dos laboratores e o ingresso nos quadros da Igreja ou nos estudos universitários, poderiam significar mudanças sociais verticais.

Le Goff alerta que "não se deve julgar que a sociedade medieval era um mundo de sedentários, de imóveis, apegados ao seu cantinho de terra cercado de bosques. A mobilidade dos homens da Idade Média foi extrema e desconcertante" (1995b, p.172):

(...) os camponeses cujos campos são, simplesmente, uma concessão mais ou menos revogável do senhor e que são frequentemente redistribuídos pela comunidade aldeã conforme a rotação dos cultivos e dos terrenos, só por vontade senhorial está ligado a sua terra; e de bom grado escapa a essa vontade, em primeiro lugar pela fuga e, depois, pela emancipação jurídica. Individual ou coletiva, a emigração campesina é um dos grandes fenômenos da demografia e da sociedade medievais. (...) o homem medieval é um perpétuo peregrino. (1995b, p.172-173)

As datas de início e término da Idade Média devem ser problematizadas, pois sendo a história um processo, os entrelaçamentos entre elementos sociais, culturais, econômicos do medievo, dos períodos anteriores (Império Romano) e dos posteriores (Idade Moderna) precisam ser considerados. Essas divisões metodológicas não são naturais, mas construções históricas e arbitrárias com fins didáticos. Nunca é demais ressaltar que a divisão do tempo histórico em idades foi instituída no século XVII pelo alemão Cristoph Cellarius e posteriormente reformulada no século XIX a partir de datas-marco que fundam a chamada "periodização clássica", adotada até hoje. Tal afirmação parece óbvia para os historiadores, todavia 
ela quase nunca é questionada pelos manuais didáticos e mesmo debatida em sala de aula.

Os reducionismos sobre a Idade Média, na obra dos Pilleti ainda aparece na comparação entre a China e a Europa do século XI. O texto utilizado pelos autores apresenta uma situação hipotética na qual um viajante europeu chega à China e "em vez de um mundo rural de barões e camponeses analfabetos com que estava familiarizado, ele encontraria uma cidade aberta (...) composta por mercadores, viajantes, funcionários do governo e trabalhadores" (2001, p.157). Em seguida propõem que os alunos escrevam um texto mostrando como seria a reação de um chinês da época ao visitar a Europa medieval.

Nessa atividade fica clara a dicotomia civilização versus barbárie. 0 exercício parece evidenciar as diferenças entre uma sociedade e outra, entretanto a afirmação "em vez de um mundo rural de barões camponeses e analfabetos" reforça a imagem da inferioridade do medievo europeu frente à sociedade chinesa, estabelecendo padrões de julgamento sem atentar para as lógicas próprias do período e suas especificidades.

É interessante sublinhar que na maioria absoluta das imagens e gravuras utilizadas pelos autores, não há contextualização das fontes, nem de sua autoria, época de produção e dados que contribuam para sua observação critica. As referências iconográficas são instrumentos poderosos do ensino, pois possibilitam entender a percepção simbólica e o imaginário de uma época. Por essa razão, não deveriam ser apresentadas como meras ilustrações, uma vez que a análise imagética é uma ferramenta eficaz para a construção do conhecimento e reflexões históricas por parte do aluno.

Ainda que se apresente como uma abordagem inovadora, inclusive questionando logo de início da obra o conceito "Idade das Trevas", o manual de autoria dos Piletti segue, no geral, uma perspectiva tradicional e linear da história medieval, reforçando preconceitos sobre o período.

Os méritos estão em propor discussões interessantes ao tentar problematizar as relações entre passado e presente. Um exemplo é uma atividade sobre as mulheres na Idade Média (2001, p.156). Os autores partem de uma reportagem de jornal que versa sobre uma jovem paquistanesa que teve seu corpo completamente queimado pelo irmão, por 
suspeita de ter tido um relacionamento ilícito com um vizinho, bem como de mulheres vítimas de estupro que foram assassinadas por suas tribos. Depois discorrem sobre o tratamento dispensado as bruxas no medievo e propõem a seguinte questão: pesquisar as condições sociais das mulheres paquistanesas e se as mulheres brasileiras sofrem discriminações (2001, p.169).

Porém, se o professor não tiver uma boa formação e entendimento sobre o conceito de bruxaria no medievo, corre o risco de fazer uma análise anacrônica e atribuir sentido atemporal e universal ao tema. Para a realização desse tipo de atividade, é necessário que as semelhanças não anulem as diferenças. Deve-se evitar que o aluno ignore as rupturas dos contextos históricos distintos, sublinhando que a percepção da alteridade e da identidade é diversa em cada sociedade e período, a depender dos valores sociais historicamente construídos.

Um exemplo de análise que não contribui para o reconhecimento das diferenças é a proposta pelos Piletti ao comentar as "Cruzadas". Os autores apresentam uma imagem do século XIII de Mario Sanudo (não encontrei referências sobre a existência desse artista) que retrata a luta entre árabes e cavaleiros cristãos durante o movimento cruzadístico e a comentam da seguinte maneira: "a imagem nos conta que, em vez de pregar, os cristãos faziam guerra; em vez de converter, condenavam a pena de morte" (2005, p.46). Também sobre as Cruzadas, Schmidt afirma que:

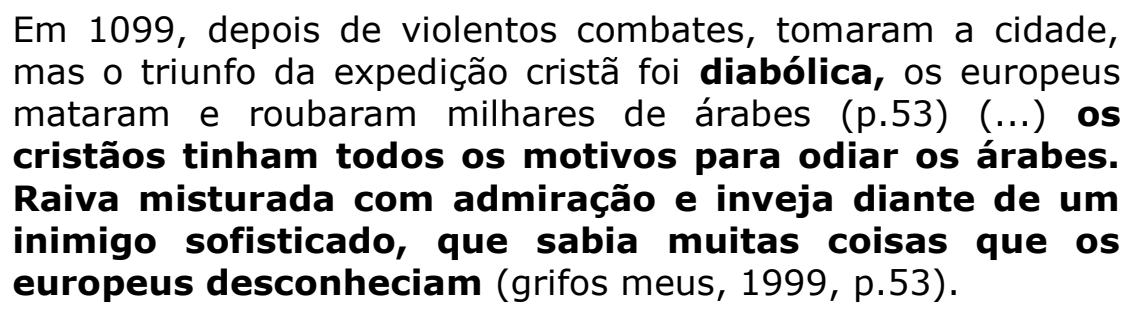

Percebe-se, nestas duas passagens de livros distintos, uma tendência a "diabolizar" os cruzados, vistos simploriamente como assassinos sanguinários. Em nenhum momento a complexidade da esfera religiosa no mundo medieval foi analisada fazendo o aluno compreender que em um estado não laico, guerra e religião podem caminhar de mãos dadas. A 
imagem do cruzado unia as funções de guerreiro e missionário religioso, em nome de um ideal maior e transcendente que era a defesa da Cristandade.

(...) O sentido da transcendência arrancava o indivíduo da sua condição particular (...) para impulsioná-lo rumo a um ideal absoluto, tal como uma terra santa a ser libertada, uma igreja a ser construída, ou então, com obstinada candura, um herege a ser queimado vivo. (MARCHI, 1991, p. 39)

Em sua obra, Roberto Mello sublinha a forte motivação religiosa e missionária do período, repleto de "perspectivas soteriológicas e escatológicas ligadas a Jerusalém, numa sociedade que não fazia grande distinção entre o sagrado e o profano, para o qual os mais insignificantes eventos cotidianos tinham uma projeção metafísica, sobrenatural" (1989, p.15)

O movimento cruzadístico aliou em si mesmo perspectivas plurais. $\mathrm{O}$ cruzado era impulsionado pelas promessas de recompensas materiais (riquezas, terras e títulos), pela realização de uma obrigação religiosa visando os cumprir os ideais missionários da Cristandade e pelo conseqüente recebimento de benefícios espirituais, dentre outros. Combater o "infiel muçulmano" era considerada uma ação santa e representava a possibilidade de salvação eterna, garantida pelas indulgências oferecidas pela Igreja aos cruzados. As Cruzadas eram a luta dos fiéis contra "os inimigos de Deus, fossem muçulmanos, heréticos, pagãos e até cristãos ortodoxos" (FRANCO JÚNIOR, 1999, p.26).

\section{A Nova História Crítica de Mário Schmidt}

Adotada por muitos anos pelo PNDL, o manual "Nova História Crítica" de Mário Schmidt só foi excluído do programa em 2008. No parecer elaborado pela comissão do MEC em 2005, os relatores o incluíram no guia com ressalvas, registrando que o livro se propunha a mostrar a história sob a "ótica dos vencidos", mas tropeçava no "maniqueísmo" e na visão "simplificada dos processos e contradições sociais". Também alertaram que 
"a anunciada perspectiva crítica associa-se mais à utilização de uma linguagem marcada pela excessiva informalidade do que pela formação de um aluno capaz de pensar e compreender o procedimento histórico" (Guia do Livro Didático, 2005, p.132-136).

O jornalista Ali Kamel foi um dos responsáveis pela exclusão da obra do Guia do Livro Didático de 2008, por denunciar que esta continuava sendo adotada na maioria das escolas, mesmo sendo de duvidosa qualidade. A crítica de Kamel foi veiculada no jornal $O$ Globo e reverberou em matérias de outros jornais da "grande imprensa" brasileira. A polêmica acabou por refletir indiretamente o conflito entre um representante dos interesses das organizações Globo (Kamel é diretor da Central Globo de Jornalismo) e Mário Schmidt, ferrenho defensor da ideologia marxista, acusado de tecer críticas indiretas à emissora em suas obras. Schmidt chegou a insinuar que as opiniões negativas a respeito de seu livro eram motivadas por interesses econômicos e ideológicos do grupo Globo que desejava beneficiar outra publicação de uma editora parceira

Conflitos à parte, o fato é que a obra de Schmidt comete inúmeros deslizes e expressa uma concepção "marxista" da História. Seu discurso é ideologicamente engajado e norteado pela luta de classes: pobres e ricos, dominados e dominantes, senhores feudais e servos, reduzindo a complexidade histórica dos fenômenos sociais e dos grupos ao viés políticoeconômico.

Vejamos apenas algumas afirmações sobre o medievo no livro de Schmidt (edição de 1999 que foi reeditada nos anos subseqüentes). As simplificações e juízos de valor permeiam toda a obra e reforçam a visão pejorativa da Idade Média: Naquela época tumultuada de guerras e destruição, de reinos que nasciam e morriam num piscar de olhos, de roubos e matanças a Igreja era a única instituição sólida (1999, p.23).

Nota-se que o autor superestima os aspectos trágicos do período passando a ideia de uma sociedade totalmente caótica, entregue a barbárie. A partir dessas afirmações o aluno desconhece outras realidades medievais, inclusive a estabilidade política, econômica e social do período que permitiu o surgimento do feudalismo. 
A supremacia da Igreja é inegável no medievo, todavia é preciso assinalar que dentro das ordens eclesiásticas surgiram importantes avanços intelectuais como a tradução de inúmeras obras clássicas que, aliadas ao espiritualismo cristão, deram origem à filosofia escolástica. A resignificação do pensamento aristotélico, a ênfase no empirismo e o rigor metodológico e dialético, são apenas algumas das significativas contribuições que antecederam a criação da ciência moderna, afastando a ideia de que no medievo apenas dogmas religiosos foram gestados. A tendência de Schmidt é mostrar uma Igreja homogênea, sem abordar as contradições e complexidades da instituição, formada por diversas ordens religiosas e movimentos distintos.

Outro deslize do livro é generalizar a vida cotidiana nobiliárquica, descrevendo os nobres como fanfarrões perdulários em contraposição a penúria dos camponeses.

\begin{abstract}
A vida do servo não era nada fácil. Eles trabalhavam um bocado enquanto os nobres viviam na diversão. (...). Os nobres divertiam-se em banquetes, nos quais bebiam, dançavam e comiam até passar mal. Adoravam roupas finas e caras, que mostravam o quanto eram ricos. Os jovens nobres gostavam de galopar a toda velocidade, assustando os servos em sua labuta, mas encantando as servas bonitas (1999, p.30-32).
\end{abstract}

Estudos recentes revelam que a vida da nobreza não era tão farta, não existiam muitos luxos e a comida era escassa e regrada em muitos feudos. Muitos nobres cavalheiros passavam meses em campo de batalha em condições adversas. O principal fundamento das relações feudais era o de fidelidade em troca de proteção, incluindo a subsistência material. Nessa relação, os servos recorrem à defesa de um senhor forte. Nesse sentido, a nobreza é uma classe privilegiada, todavia existiam senhores justos. Somente uma visão superficial da sociedade medieva contrapõe, de forma extremista, a tirania nobiliárquica e a humilhação camponesa. Entre os senhores e os camponeses há um número de situações intermediárias de hierarquia dos dois lados, uma pluralidade de modalidades que desconstroem a imagem fixa, imóvel e definitiva dessas categorias tão estereotipadas. 
Referindo-se ao pensamento inovador de Roberto Lopez exposto na obra clássica Nascimento da Europa, Ruy Nunes assinala que o feudalismo não nasceu de princípios abstratos (como a concepção de Estado da Antiguidade), mas das práticas particulares e, porque não dizer, de "solidariedades voluntárias expressas nos ritos de vassalagem e benefício" sendo mais uma troca do que uma mera relação de imposição dos senhores feudais (1979, p.52).

A referência ao galope ligeiro dos nobres e suas tendências libertinas, mais parecem uma tentativa de sugerir comparações anacrônicas com o comportamento de alguns jovens burgueses da atualidade e a exibição de seus carros possantes, utilizados para seduzir garotas, em uma clara referência misógina uma vez que tal atitude encantava "as servas bonitas", esquecendo que o conceito de beleza é um dado muito particular de cada época.

É preciso recordar que a Idade Média é um período longo de cerca de quinze séculos e as características do proeminente sistema feudal se desenvolveram de forma específica nos diferentes reinos da Europa e demais partes do mundo. A obra de Schmidt silencia essas distinções ao abordar o medievo de maneira homogênea e imutável, como um universo isento de multiplicidades.

Referindo-se a educação na Idade Média o autor faz afirmações categóricas: "os servos jamais iam à escola" (1999, p.32) e que: "na Europa medieval quase todos eram analfabetos. Geralmente só os padres e monges sabiam ler e escrever" (1999, p.23); "os nobres não precisavam ser alfabetizados para montar cavalo, vestir armadura, enfiar a espada nos outros e cobrar tributos feudais" (1999, p.51).

Contrapondo esse pensamento, na historiografia há exemplos em profusão de personagens das camadas baixas que por meio do ensino galgaram condições sociais privilegiadas no medievo. Segundo Pernoud, assim como muitos clérigos e nobres, filhos de servos e camponeses freqüentavam a escolas. Estudantes de classes inferiores mais dotados tomavam o caminho da universidade, na maioria das vezes, tutelados pela Igreja que vai incentivar seus estudos e absorvê-los em seus quadros. 
Suger, que governava a França durante a cruzada de Luis VII, é filho de servos; Maurice de Sully, o bispo de Paris que mandou construir Notre-Dame, nasceu de um mendigo, São Pedro Damião, na sua infância, guarda porcos, e uma das mais vivas luzes da ciência medieval, Gerbert d' Aurillac, é igualmente pastor; o papa Urbano VI é filho de um pequeno sapateiro de Troyes e Gregório VII, o grande papa da Idade Média, de um pobre cabreiro. Inversamente, muitos dos grandes senhores são letrados cuja educação não devia diferir muito da dos clérigos: Roberto, o Piedoso, compõe hinos e seqüências latinas; Guilherme IX, príncipe de Aquitânia, é o primeiro, cronologicamente, dos trovadores; Ricardo Coração de Leão deixou-nos poemas, assim como senhores de Ussel, dos Baux e tantos outros. (PERNOUD, 1981, p.97)

Ao contrário do que pregam os manuais didáticos, o saber é respeitado na Idade Média. "Com desonra morra merecidamente quem não gosta de livro" dizia um provérbio. (PERNOUD, 1981, p.103). Por outro lado "(...) a pobreza não era um obstáculo, uma vez que o decurso dos estudos podia ser inteiramente gratuito, da escola da aldeia, ou antes da paróquia, até a Universidade". (PERNOUD, 1981, p.104)

Outro aspecto é o prestígio do conhecimento consuetudinário equiparado à cultura letrada. No medievo podia-se ser um bom advogado sem saber ler e escrever, porque ele poderia ser profundo conhecedor do costume, dominar a aplicação prática do direito e desenvolver boa oratória, sem conhecer o alfabeto. Uma tese de doutoramento da Universidade medieval não era impressa, mas sim um debate. Entender essas dinâmicas dos costumes é fundamental para se conhecer um pouco do mundo medieval.

A afirmação de Schmidt de que os nobres não precisavam ser "alfabetizados para montar cavalo, vestir armadura, enfiar a espada nos outros e cobrar tributos feudais" é completamente arbitrária, explicitando sua aversão às funções constitutivas da nobreza, provavelmente comparada aos mantenedores de privilégios na sociedade atual.

Um dos exercícios do livro de Schmidt intitulado "reflexões críticas" fornece o seguinte enunciado para reflexão: "Para homens e mulheres da sociedade medieval, Deus tinha dividido a sociedade em três grupos: os que trabalham, os que guerreavam e os que oravam e cuidavam dos livros, ou seja, os servos, os nobres e os membros da Igreja. Debata a seguinte ideia: 
"A sociedade brasileira atual é semelhante à sociedade européia. Afinal de contas, os trabalhadores e empresários alimentam a sociedade; os militares e os policiais a protegem e os intelectuais (cientistas, economistas, historiadores, etc) procuram entendê-la." (1999, p.37). Há nessa tarefa uma evidente influência do conceito de divisão de classes, proposta pelo materialismo histórico marxista, teoria já bastante questionada nos meios acadêmicos que reflete a corrente ideológica do autor.

Também os autores já analisados, Nelson Piletti e Claudino Piletti (2005, p.48), no tópico a Nova Evangelização utilizam uma entrevista de Leonardo Boff discorrendo sobre a necessidade de a Igreja contemporânea estimular o diálogo entre as culturas e respeitar as diferenças étnicas e sociais dos povos. A seguir sugerem o seguinte questionamento: Que papel deve desempenhar a Igreja na atualidade, segundo Boff, e o que esse difere do representado pela Igreja medieval?

O perigo dessa proposição é levar a uma análise rasa e anacrônica de um período histórico, estabelecendo comparações simplistas que acabam por valorizar as estruturas do presente em detrimento do passado. 0 exercício traz uma opinião acerca do papel eclético da Igreja de hoje que acaba por induzir uma contraposição com o autoritarismo da ortodoxia eclesiástica medieval. Entretanto, o aluno desconhece que essa perspectiva não corresponde ao pensamento oficial do clero atual, uma vez que Leonardo Boff foi excomungado em 1992 por professar ideias libertárias. Não percebe a Idade Média como uma época plural e de contrastes, pois a mesma Igreja que cerceou e excluiu, perseguindo hereges e infiéis, concomitantemente acolheu em sua estrutura características e elementos de diversos povos. Tais referências se encontram expressas tanto na liturgia e nos rituais, ao resignificar diversas festas pagãs, como na própria tradição bíblica, ao incluir referencias greco-romanas, judaicas e babilônicas no texto cristão.

Uma comparação simplista do mundo atual com o medievo pode dificultar a capacidade do aluno de entender as estruturas do passado nas suas especificidades, sem recorrer a referências valorativas do tempo presente. 
(...) a falta de consciência muitas vezes dá lugar a visões anacrônicas do passado, e não raro, em nome das aproximações mais "didáticas", os manuais esbarram na indulgência temporal (...) Esses vários impasses fazem com que muitos autores de obras didáticas trilhem o caminho simplificado de abandonar certos esquemas aceitos e altamente vendáveis. (FERREIRA, 2008, p.91)

Não que os estudos comparativos não sejam importantes, mas é preciso tomar certos cuidados metodológicos para não discriminar o passado afim ressaltar a identidade presente. Lopez explica muito bem essa confusão quando afirma que:

(...) o feudalismo foi um sistema de governo, como a democracia liberal ou o socialismo, aos quais deixou muitas ruínas a desobstruir, mas também material a recuperar. Hoje, é tão fácil criticá-lo como provar a superioridade do telefone sobre o pombo correio; o que não impede que, antes da eletricidade, o pombo tenha prestado serviço (1965, p. 166).

Apesar da perspectiva reducionista ainda persistir, é certo que alguns avanços e modificações foram incorporados pelos manuais didáticos produzidos nos últimos anos. A mudança mais significativa talvez seja a tentativa de reparar o esquecimento de personagens e fatos que foram silenciados pelo livro didático, dando visibilidade à perspectiva de grupos historicamente marginalizados como é o caso das mulheres, negros, crianças e religiões não cristãs. Outro ponto inovador é o estímulo a uma maior articulação entre passado e presente, possibilitando que aluno tome consciência do processo histórico (continuidades/ descontinuidades) e sua relação com a realidade contemporânea. Por fim, podemos verificar a adoção de novas linhas de pesquisa historiográfica, especialmente devido à necessidade de adequação aos PCN's.

Um próximo passo seria estimular uma formação mais adequada de um corpo docente mediador na construção do conhecimento, capaz de analisar e utilizar o material didático de forma crítica e criativa, ao invés de superestimá-lo ou mesmo aboli-lo. 


\section{Referências}

ARAÚJO, E. O teatro dos vícios: transgressão e transigência na sociedade urbana colonial. Rio de Janeiro: José Olympio, 1993.

BITTECOURT, C. M. F. O livro didático não é mais aquele. Revista Nossa História, ano I, n. 2, dezembro de 2003, p.52-54.

2004. . Ensino de História fundamentos e métodos, São Paulo: Cortez,

BLOCH, M. Os reis taumaturgos: O caráter sobrenatural do poder régio França e Inglaterra. São Paulo: Cia das Letras, 1993.

BONNASSIE, P. Dicionário de História Medieval. Lisboa: D. Quixote, 1985.

BRASIL. Guia de Livros Didáticos PNLD 2008: História/Ministério da Educação. - Brasília: MEC, 2007. 124 p. - (Anos Finais do Ensino Fundamental).

BRASIL. Parâmetros Curriculares Nacionais:/História/Secretaria de Educação Fundamental - Brasília: MEC/SEF, 1998.

CESARE, M. Grandes Pecadores, Grandes Catedrais. São Paulo, Martins Fontes, 1991.

COELHO, M. F. A justiça d'além-mar. Lógicas jurídicas feudais em Pernambuco (séc. XVIII). Recife: Ed. Massangana/Fundação Joaquim Nabuco, 2009.

FERREIRA, M. de M. Desafios do ensino de História. In: Revista Estudos Históricos. Rio de Janeiro: FVG, v. 21, n. 41, p.79-94.

FONSECA, S. G. Didática e prática de ensino de História: experiências, reflexões e aprendizados. Campinas, SP: Papirus, 2003.

FRANCO JR, H. As Cruzadas - Guerra Santa entre Ocidente e Oriente. $1^{\mathrm{a}}$ ed. São Paulo: Editora Moderna, 1999.

FISCARELLI, R. B. de O. Material Didático e prática docente. In: Encontro Iberoamericano de educação. Alcalá de Henares, 2006.

KAMEL, A. O que ensinam às nossas crianças. Artigo de opinião em $O$ Globo - 18/09/2007.

$-01 / 10 / 2007$

KOLING, P. J. O ensino de História da América na educação básica reflexões a partir de manuais didáticos e obras utilizadas em escolas públicas no 
Oeste do Paraná. In: Anais Eletrônicos do VIII Encontro Internacional da ANPHLAC, Vitória, 2008.

LE GOFF, J. Para um novo conceito de Idade Média: tempo, trabalho e cultura no Ocidente. Lisboa: Editorial Estampa, 1995a. 1995b.

. A civilização do Ocidente medieval. v 1., Lisboa: Editorial Estampa,

LOPEZ, R. S. Nascimento da Europa. Lisboa, Rio de Janeiro, Edições Cosmos, 1965.

MACEDO, J. R. Repensando a Idade Média no Ensino de História. In: KARNAL, Leandro (Org.). História na sala de aula: conceitos, práticas e propostas. São Paulo: Contexto, 2008.

MELLO, J. R. As Cruzadas. Série Princípios. São Paulo: Editora Ártica, 1989.

MELO, C. F. de C. B. de. Senhores da História e do esquecimento: a construção do Brasil em dois manuais didáticos de História na segunda metade do século XIX. Belo Horizonte, MG: Argumentum, 2008.

MIRANDA, S. R., LUCA, T. R. de. O livro didático de história hoje: um panorama a partir do PNLD. Revista Brasileira de História, São Paulo, v.24, n. 48 , p.123-144, 2004.

MONTEIRO, A. M.. Professores e manuais didáticos: narrativas e leituras no ensino de história. Rio de Janeiro Ed. FGV, 2009.

NUNES, R. A. da C. História da Educação na Idade Média. São Paulo, EDUSP, 1979.

PERNOUD, R. A Mulher nos Tempos das Cruzadas. Campinas, São Paulo: Editora Papirus, 1993.

. Idade Média: o que não nos ensinaram. Rio de Janeiro: Agir, 1994. Luz sobre Idade Média. Sintra: Europa-América, 1981.

PEREIRA, N. M.; GIACOMONI, M. P. Possíveis Passados: representações da Idade Média no Ensino de História. Porto Alegre: Zouk, 2008.

PILETTI, Claudino; PILETTI, Nelson. História e vida integrada. 4. vols. 2 ed., São Paulo: Ática, 2007.

. História e Vida. 4. vols. 1.ed. São Paulo: Ática, 1989.

História e Vida integrada. Nova edição reformada e atual. São

Paulo: Editora Ática, 2 ed., 2006.

. História e Vida: das origens da humanidade à Idade Média. v.3.

São Paulo: Editora Ática, 25 ed., 2001. 
SCHIMIDT, M. Nova História Critica. São Paulo: Nova Geração, 1999. 